\title{
HUBUNGAN STATUS PEKERJAAN IBU DENGAN MOTIVASI PEMBERIAN ASI EKSKLUSIF DI WILAYAH KERJA PUSKESMAS MENGWI III KABUPATEN BADUNG
}

\author{
Ni Made Sri Ardhia Padmasari' ${ }^{1}$, Ida Arimurti Sanjiwani ${ }^{2}$, I Made Suindrayasa ${ }^{3}$ \\ ${ }^{1}$ Mahasiswa Program Studi Sarjana Keperawatan Fakultas Kedokteran Universitas Udayana \\ ${ }^{2,3}$ Staff Dosen Program Studi Sarjana Keperawatan Fakultas Kedokteran Universitas Udayana \\ Alamat Korespondensi: nimadesap@gmail.com
}

\begin{abstract}
Abstrak
Pemberian ASI eksklusif sangat penting bagi pertumbuhan dan perkembangan bayi. Cakupan pemberian ASI eksklusif di Bali pada tahun 2015 masih belum mencapai target angka yang diharapkan. Motivasi seorang ibu sangat menentukan dalam pemberian ASI eksklusif selama enam bulan Tujuan dari penelitian ini untuk mengetahui hubungan antara status pekerjaan ibu dengan motivasi pemberian ASI eksklusif. Penelitian ini merupakan penelitian ko relasional dengan pendekatan cross-sectional. Teknik pengambilan sampel yang digunakan yaitu dengan purposive sampling yang terdiri dari 90 ibu yang memiliki bayi berusia 0-6 bulan. Pengumpulan data dilakukan dengan menggunakan kuesioner. Hasil dari uji chi-square diperoleh $p$ value $0,003(\mathrm{p}<0,05)$ artinya terdapat hubungan antara status pekerjaan ibu dengan motivasi pemberian ASI eksklusif. Penelitian ini diharapkan dapat menjadi dasar bagi petugas kesehatan untuk memberikan promosi kesehatan terkait pentingnya pemberian ASI eksklusif dan juga untuk meningkatkan pemberdayaan masyarakat dalam upaya meningkatkan cakupan pemberian ASI eksklusif. Ibu diharapkan aktif mencari informasi tentang ASI eksklusif sehingga dapat meningkatkan motivasi ibu dalam memberikan ASI eksklusif.
\end{abstract}

Kata Kunci: ASI Eksklusif, Motivasi, Status Pekerjaan Ibu

\begin{abstract}
Exclusive breastfeeding is very important for infant growth and development. In 2015, the rate of exclusive breastfeeding in Bali was still under the targeted. Mother's motivation is crucial in giving exclusive breastfeeding for six months. The aim of this study was to determine the relationship between the mother's employment status with the motivation of exclusive breastfeeding. This study was a correlational study with a cross-sectional approach. The sampling technique was used purposive sampling which consisted of 90 mothers who had infants aged 0-6 months. Data collection using a questionnaire. The results of the chi-square test obtained $p$ value $0.003(\mathrm{p}<0.05)$ which means that there was a relationship between the mother's employment status with the motivation for exclusive breastfeeding. This research is expected become the basis for health workers to provide health promotion about the importance of exclusive breastfeeding and also to improve community empowerment as an effort to increase the coverage of exclusive breastfeeding. Mothers are expected to actively seek information about exclusive breastfeeding so that it can increase the mother's motivation to give exclusive breastfeeding.
\end{abstract}

Keyword: Exclusive Breastfeeding, Motivation, Mother's Employment Status 


\section{PENDAHULUAN}

Angka Kematian Bayi (AKB) merupakan salah satu indikator yang dapat menggambarkan derajat kesehatan pada masyarakat. AKB di Indonesia sebesar 24 pers 1000 kelahiran hidup di tahun 2017. Angka tersebut masih tergolong cukup tinggi bila dibandingkan dengan beberapa negara di kawasan ASEAN (BKKBN, 2018). AKB di Bali tahun 2017 sebesar 4,8 per 1000 kelahiran hidup (Dinkes Bali, 2018). Kematian bayi di Indonesia dapat disebabkan oleh kelahiran prematur, infeksi saluran napas, diare serta masalah gizi seperti kurang protein dan kalori. Salah satu upaya untuk mengurangi AKB yaitu dengan memperbaiki gizi bayi. Pemberian Air Susu Ibu (ASI) eksklusif merupakan makanan yang tepat selama enam bulan pertarna kehidupan bayi (BAPPENAS, 2012).

ASI eksklusif merupakan cairan putih yang dihasilkan melalui proses laktasi dan diberikan sejak bayi lahir hingga berusia enam bulan tanpa diberikan tambahan minum atau makanan apapun (Retiyansa, 2018). ASI mengandung immunoglobulin dan protein untuk meningkatkan daya tahan tubuh, sehingga bayi yang diberikan ASI lebih jarang mengalami sakit terutama di bulanbulan awal kehidupannya (Rahmadhani, Lubis \& Edison, 2013).

Cakupan pemberian ASI eksklusif di Indonesia masih belum mencapai target angka yang diharapkan (Kemenkes RI, 2015). Cakupan pemberian ASI eksklusif di Provinsi Bali pada tahun sebesar 72,8\% (Dinkes Bali, 2016). Angka tersebut masih belum mencapai target cakupan pemberian ASI eksklusif sebesar 80\% (CNN Indonesia, 2018). Data yang diperoleh dari Profil Kesehatan Kabupaten Badung tahun 2017 Cakupan pemberian ASI eksklusif terendah yaitu di wilayah kerja Puskesmas Mengwi III yaitu sebesar (50\%).
Penyebab rendahnya cakupan pemberian ASI eksklusif karena kebanyakan ibu yang memiliki bayi bekerja sehingga tidak memiliki kesempatan untuk memberikan ASI eksklusif dan cenderung memilih memberikan bayinya susu formula. Hal ini dapat berdampak pada bayi menjadi tidak memiliki daya tahan tubuh yang baik sehingga mudah mengalami sakit dan bayi tidak mendapatkan zat makanan bergizi dan berkualitas tinggi sehingga dapat menghambat kecerdasan bayi (Depkes, 2010).

Kebijakan bagi tenaga kerja perempuan menjadi salah satu kendala dalam menyukseskan program ASI Eksklusif. Ibu hanya dapat mendampingi dan menyusui bayi secara eksklusif sekitar dua bulan saja. Hal ini dikarenakan ibu hanya mendapatkan cuti melahirkan sekitar 12 minggu dimana empat minggu pertama sering harus diambil sebelum ibu melahirkan. Setelah itu ibu harus kembali bekerja dan ibu sering terpaksa untuk berhenti menyusui (Armini, Somoyani \& Budiyani, 2015). Berdasarkan penelitian Okawary (2015) para ibu yang tidak bisa memberikan ASI eksklusif dan beralih ke susu formula terjadi pada ibu yang bekerja, terutama di perkotaan.

Motivasi seorang ibu sangat menentukan dalam pemberian ASI eksklusif selama enam bulan (Wirawan dalam Nuryawati, 2015). Motivasi pemberian ASI eksklusif dapat dipengaruhi oleh beberapa hal yaitu usia, pendidikan, status pekerjaan, pengetahuan, dukungan dari keluarga, pendapatan keluarga, jumlah anak dan peran petugas kesehatan. Motivasi mempunyai arti sebuah dorongan internal dan eksternal seseorang dalam melakukan sesuatu untuk mencapai tujuan (Notoatmodjo, 2009). Penelitian Nuryawati (2015) menunjukkan bahwa Ibu dengan motivasi tinggi akan lebih baik dalam pemberian ASI eksklusif, hal ini 
dikarenakan dorongan dalam diri sendiri dan keluarga sangat kuat sehingga ibu dapat memberikan ASI secara eksklusif selama enam bulan, sedangkan yang merniliki motivasi rendah dapat berdampak sebaliknya yaitu seperti memberikan susu formula atau pemberian minuman dan makanan tambahan saat bayi berusia kurang dari enam bulan.

Berdasarkan studi pendahuluan yang dilakukan pada bulan Februari tahun 2019 di Wilayah kerja Puskesmas Mengwi III yang terdiri dari empat desa yaitu Sempidi, Lukluk, Sading dan Penarungan. Peneliti melakukan wawancara pada ibu yang memiliki bayi usia 0-6 bulan, pada ibu yang bekerja mengatakan ingin memberikan ASI saja pada bayinya tetapi karena terbatasnya waktu kebersamaan dengan bayi dan tidak tersedianya fasilitas menyusui ditempat kerja, sehingga ibu memberikan susu formula pada bayinya. Sedangkan, ibu yang tidak bekerja mengatakan memberikan ASI eksklusif tanpa tambahan makanan apapun. Hal ini dikarenakan ibu menganggap pemberian ASI dapat meningkatkan daya tahan tubuh anaknya sehingga tidak mudah sakit. Berdasarkan latar belakang tersebut, maka penulis ingin meneliti lebih lanjut mengenai hubungan status pekerjaan bu dengan motivasi pemberian ASI eksklusif.

\section{METODE PENELITIAN}

Penelitian ini merupakan jenis penelitian ko relasional dengan pendekatan cross-sectional untuk mengetahui hubungan status pekerjaan ibu dengan motivasi pemberian ASI eksklusif di Wilayah Kerja Puskesmas Mengwi III Kabupaten Badung.

Populasi dalam penelitian ini adalah ibu yang memiliki bayi usia 0-6 bulan di Wilayah Kerja Puskesmas Mengwi III Kabupaten Badung sebanyak 117 orang. Berdasarkan teknik purposive sampling diperoleh sampel penelitian sebanyak 90 orang.

Pengumpulan data dilakukan dengan menggunakan kuesioner motivasi pemberian ASI eksklusif yang berisi data demografi dan pernyataan dengan skala Likert sebanyak 26 butir

Pengumpulan data dilakukan selama sebulan dari bulan Mei sampai Juni di Wilayah Kerja Puskesmas Mengwi III. Kabupaten Badung. Peneliti dibantu oleh empat orang asisten peneliti. Setelah diperoleh izin penelitian, peneliti melakukan pengumpulan data pada ibu yang memiliki bayi usia 0-6 bulan dengan memberikan lembar kuesioner. Kriteria motivasi ditentukan berdasarkan cut off point dari jumlah skor kuesioner yaitu motivasi rendah $(<81)$ dan motivasi tinggi (>81). Penelitian ini telah lolos uji kelayakan etik oleh Komisi Etik Fakultas Kedokteran Universitas Udayana.

\section{HASIL PENELITIAN}

Hasil distribusi frekuensi kkarakteristik responden didapatkan hasil bahwa rata-rata usia responden yaitu 26,50 tahun, rata-rata usia bayi yaitu 4,00 bulan. Sebagian besar responden memiliki urutan anak/anak ke-1 sebanyak 50 orang $(55,6 \%)$ dan jumlah anak 1 orang yaitu 50 orang $(55,6 \%)$. Sebagian besar responden memiliki tingkat pendidikan SMA yaitu sebanyak 44 orang $(48,9 \%)$. Pekerjaan responden sebagai Ibu Rumah Tangga (IRT) sebanyak 42 orang $(47,7 \%)$, bekerja sebagai pegawai swasta sebanyak 41 orang $(45,6 \%)$ dan sebagai PNS sebanyak 7 orang $(7,8 \%)$. Sebagian besar responden memiliki penghasilan keluarga $>\mathrm{Rp}$ 2.700.000 per bulan yaitu sebanyak 49 orang $(54,6 \%)$.

Penelitian ini mendapatkan hasil gambaran status pekerjaan ibu. Distribusi frekuensi data status pekerjaan ibu dapat dilihat pada tabel 1 .

Tabel 1. Hasil Distribusi Status Pekerjaan Ibu 


\begin{tabular}{ccc}
\hline Variabel Status Pekerjaan Ibu & Frekuensi (n) & Persentase (\%) \\
\hline Tidak Bekerja & 42 & 46,7 \\
\hline Bekerja & 48 & 53,3 \\
\hline
\end{tabular}

Data pada tabel 1. Menunjukkan bahwa sebagian besar status pekerjaan ibu adalah bekerja sebanyak 48 orang $(53,3 \%)$.
Berdasarkan penelitian ini, hasil distribusi frekuensi data motivasi pemberian ASI eksklusif dapat dilihat pada tabel 2 .

Tabel 2. Hasil Distribusi Data Motivasi Pemberian ASI Eksklusif

Variabel Motivasi Pemberian ASI Eksklusif.

\begin{tabular}{ccc}
\hline Variabel Motivasi Pemberian ASI Eksklusif & Frekuensi $(\mathbf{n})$ & $\begin{array}{c}\text { Persentase } \\
(\boldsymbol{\%})\end{array}$ \\
\hline Motivasi Rendah & 44 & 48,9 \\
\hline Motivasi Tinggi & 46 & 51,1 \\
\hline
\end{tabular}

Hasil penelitian pada tabel 2 menunjukkan bahwa sebagian besar motivasi pemberian ASI eksklusif yaitu motivasi tinggi sebanyak 46 orang $(51,1 \%)$

Tabel 3. Hubungan Status Pekerjaan Ibu dengan Motivasi Pemberian ASI Eksklusif di Wilayah Kerja Puskesmas Mengwi III Kabupaten Badung

\begin{tabular}{|c|c|c|c|c|c|c|}
\hline & & \multicolumn{4}{|c|}{ Motivasi Pemberian ASI Eksklusif } & \multirow{3}{*}{ Nilai p } \\
\hline & & \multicolumn{2}{|c|}{ Rendah } & \multicolumn{2}{|c|}{ Tinggi } & \\
\hline & & $\mathbf{n}$ & $\%$ & $\mathbf{n}$ & $\%$ & \\
\hline \multirow{3}{*}{$\begin{array}{r}\text { Status } \\
\text { Pekerjaan Ibu }\end{array}$} & Tidak & 13 & 31,0 & 29 & 69,0 & \multirow{4}{*}{0,003} \\
\hline & Bekerja & & & & & \\
\hline & Bekerja & 31 & 64,6 & 17 & 35,4 & \\
\hline \multirow{2}{*}{\multicolumn{2}{|c|}{ Total }} & 44 & 48,9 & 46 & 51,1 & \\
\hline & & \multicolumn{5}{|c|}{ OR $(95 \%$ CI $)=0,246(0,102-0,594)$} \\
\hline
\end{tabular}

Berdasarkan tabel 3 diperoleh hasil analisis antara status pekerjaan ibu dengan motivasi pemberian ASI eksklusif bahwa ibu yang tidak bekerja cenderung memiliki motivasi tinggi dalam pemberian ASI eksklusif yaitu sebanyak 29 orang $(69,0 \%)$, sedangkan ibu yang bekerja cenderung memiliki motivasi rendah dalam pemberian ASI eksklusif yaitu sebanyak 31 orang $(64,6 \%)$. Uji statistik menggunakan Chi-Square diperoleh nilai signifikansi $p(0,003)$ lebih kecil dari nilai $\alpha(<0,05)$ yang menunjukkan bahwa ada hubungan yang bermakna antara status pekerjaan ibu dengan motivasi pemberian ASI eksklusif. Nilai odd Ratio (OR) = 0,246 artinya ibu yang tidak bekerja cenderung memiliki motivasi 0,246 kali lebih tinggi untuk memberikan ASI eksklusif dibandingkan ibu yang bekerja.

\section{PEMBAHASAN}

Status pekerjaan merupakan jenis kedudukan seseorang dalam melakukan suatu kegiatan atau pekerjaan sesuai dengan kapasitas dan keahliannya (BPS, 2019). Hasil analisis status pekerjaan ibu menunjukkan bahwa mayoritas ibu menyusui memiliki status bekerja yaitu sebanyak 48 orang $(53,3 \%)$. Hal ini berarti bahwa ibu lebih cenderung memiliki kegiatan atau pekerjaan diluar rumah.

Penelitian yang dilakukan Ramadhani (2014) terhadap 54 responden menunjukkan sebagian besar responden bekerja yaitu sebanyak 28 orang $(60,9 \%)$. Di daerah perkotaan dimana relatif lebih 
banyak ibu berstatus bekerja dimana situasi ditempat kerja yang belum mendukung praktik pemberian ASI seperti belum tersedia tempat memerah dan menyimpan ASI sehingga ibu kesulitan untuk menyusui bayinya secara eksklusif (Okawary, 2015). Ibu yang tidak bekerja cenderung memiliki waktu yang lebih banyak untuk selalu mendampingi bayinya, sehingga dapat memberikan ASI pada bayinya kapan pun bayi ingin menyusu. Ibu dapat langsung menyusui bayinya tanpa repot memerah dan menyimpan ASI (Wijayanti, Sumiyarsih \& Nugraheni, 2014).

Motivasi merupakan dorongan dasar dalam diri seseorang baik secara sadar atau tidak sadar yang menggerakkan seseorang dalam bertindak untuk mencapai suatu tujuan tertentu (Elly, 2013). Hasil dari penelitian diketahui bahwa responden yang termasuk kategori motivasi tinggi dalam pemberian ASI eksklusif yaitu sebanyak 48 orang $(53,3 \%)$ dan yang termasuk kategori motivasi rendah sebanyak 42 orang $(46,7 \%)$.

Walaupun sebagian besar responden termasuk dalam kategori motivasi tinggi namun masih banyak didapatkan responden yang memiliki motivasi rendah. Hal ini tergantung kesediaan ibu untuk memberikan ASI eksklusif. Motivasi sangat diperlukan oleh setiap orang sebagai pendorong untuk mencapai tujuan tertentu (Ribek \& Kumalasari, 2014). Hasil penelitian ini dapat menunjukkan bahwa setiap ibu harus memiliki dorongan, keinginan atau kemauan dalam memberikan ASI secara eksklusif, dimana keberhasilan dalam memberikan ASI sangat dipengaruhi oleh motivasi dari ibu sendiri. Penelitian ini sejalan dengan penelitian yang dilakukan oleh Listyanigrum (2016) bahwa didapatkan hasil dari 37 responden sebagian besar responden memiliki motivasi tinggi dalam pemberian ASI eksklusif yaitu sebanyak 19 orang $(51,4 \%)$.

Hasil dari penelitian ini menunjukkan bahwa terdapat hubungan antara status pekerjaan dengan motivasi pemberian ASI eksklusif pada responden. Berdasarkan penelitian, ibu yang tidak bekerja memiliki motivasi tinggi dalami pemberian ASI eksklusif sebanyak 29 orang, sedangkan ibu yang bekerja memiliki motivasi rendah dalam pemberian ASI eksklusif sebanyak 31 orang. Penelitian yang dilakukan oleh Pratiwi (2015) menunjukkan adanya perbedaan motivasi pemberian ASI eksklusif terhadap ibu yang bekerja dan tidak bekerja bahwa pada kelompok ibu bekerja sebagian besar memiliki motivasi pemberian ASI eksklusif yang rendah, sedangkan pada kelompok ibu tidak bekerja sebagian besar memiliki motivasi pemberian ASI eksklusif yang tinggi.

Menurut Depkes (2012) pekerjaan merupakan salah satu kendala ibu untuk memberikan ASI eksklusif kepada bayinya. Chatterji dan Frick (2005) mengungkapkan bahwa kembali bekerja pada tiga bulan pertama setelah ibu melahirkan sangat berhubungan dengan penurunan motivasi untuk menyusui sebesar $16 \%-18 \%$.

Faktor yang menyebabkan ibu kurang termotivasi untuk memberikan ASI eksklusif salah satunya karena ibu bekerja lebih memprioritaskan pekerjaannya dibandingkan dengan pemberian ASI Eksklusif (Pratiwi, 2015). Ketatnya aturan jam kerja, lokasi tempat kerja yang jauh dari tempat tinggal dapat menghambat ibu untuk memberikan ASI pada bayinya dan dapat mempengaruhi motivasi pemberian ASI eksklusif yang dimilikinya (Nurlely, 2012). Soetjiningsih (2012) mengungkapkan ibu merasa dilema untuk memberikan ASI eksklusif dan akan cenderung memilih untuk memberikan susu formula sebagai 
pengganti ASI eksklusif saat bayi ditinggal bekerja.

Ibu tidak bekerja lebih termotivasi untuk memberikan ASI eksklusif karena memiliki lebih banyak waktu bersama bayinya sehingga dapat menyusui lebih lama dari pada ibu yang bekerja (Dahlan dkk, 2013). Ibu tidak bekerja juga menyadari bahwa ASI eksklusif dapat menghemat pengeluaran karena ASI selalu ada kapan pun bayi membutuhkan sehingga ibu lebih tertarik untuk memberikan ASI eksklusif (Sringati, 2016).

Penelitian Kartikasari dan Afifah (2009) menyebutkan bahwa faktor pendukung pemberian ASI eksklusif pada ibu bekerja yaitu adanya fasilitas khusus untuk menyusui atau memerahi ASI di tempat kerja. Sedangkan faktor pendukung pemberian ASI eksklusif pada ibu yang tidak bekerja yaitu dukungan dari keluarga. Rahman (2017) mengemukakan bentuk dukungan keluarga berupa pemberian bantuan dalam bentuk materi, bantuan fisik atau sikap positif dari keluarga untuk membantu ibu dalam proses menyusui. Dukungan dari keluarga sangat penting untuk mendorong ibu dalam meningkatkan kepercayaan diri sehingga dapat meningkatkan kepercayaan diri sehingga dapat meningkatkan motivasi ibu dalam memberikan ASI eksklusif untuk anaknya (Andarini, 2018).

Dalam penelitian ini peneliti mengalami keterbatasan selama penelitian yaitu pengambilan data penelitian yang dilakukan secara door to door dan beberapa responden mendapatkan waktu pengambilan data pada saat melakukan pekerjaan rumah, menjelang jam berangkat kerja dan pada waktu pulang kerja sehingga responden akan cenderung lebih cepat dalam menyelesaikan pengisian kuesioner tersebut dan dapat menimbulkan potensi ketidakjujuran saat pengisian kuesioner.

\section{KESIMPULAN DAN SARAN}

Ibu menyusui di Wilayah Kerja Puskesmas Mengwi III berstatus bekerja yaitu sebanyak 48 orang $(53,3 \%)$ dan yang berstatus tidak bekerja sebanyak 42 orang (46,7\%). Ibu menyusui memiliki motivasi pemberian ASI eksklusif yang tinggi yaitu sebanyak 46 orang $(51,1 \%)$ dan yang memiliki motivasi rendah sebanyak 44 orang $(51,1 \%)$. Hasil uji chi-squares menunjukkan ada hubungan antara status pekerjaan ibu dengan motivasi pemberian ASI eksklusif di Wilayah Kerja Puskesmas Mengwi III Kabupaten Badung diperoleh nilai $\mathrm{p}<0,05$ yaitu sebesar 0,003 .

Bagi petugas kesehatan di Wilayah Kerja Puskesmas Mengwi III diharapkan dapat meningkatkan pemberdayaan masyarakat dengan menggerakkan kader kesehatan dalam upaya meningkatkan cakupan pemberian ASI eksklusif. Meningkatkan promosi kesehatan terkait pentingnya pemberian ASI serta memberikan motivasi kepada ibu yang bekerja maupun tidak bekerja agar dapat memberikan ASI eksklusif padam bayinya. Bagi ibu diharapkan mampu meningkatkan pemberian ASI eksklusif serta lebih aktif mencari informasi tentang ASI eksklusif dan manfaat dari ASI eksklusif sehingga motivasi ibu dalam memberikan ASI eksklusif meningkat. Bagi peneliti selanjutnya, sebagai penyempurnaan penelitian diharapkan dapat meneliti faktor-faktor lain yang mempengaruhi motivasi pemberian ASI eksklusif.

\section{DAFTAR PUSTAKA}

Andarini. (2018). Hubungan Dukungan Keluarga dengan Pemberian ASI Eksklusif di Desa Bubakan Kecamatan Girimarto Kabupaten Wonogiri. Naskah Publikasi. Universitas Muharnmadiyah Surakarta. Diakses dari: http://eprints.ums.ac.id/ 
BAPPENASs. (2012). Laporan Pencapaian Tujuan Pembangunan Milenium di Indonesia 2011. Diakses dari: https://www.bappenas.go.id/

BKKBN. (2018). Survey Demografi dan Kesehatan Indonesia (SDKI) 2017. Diakses dari: https://e-koren.bkkbn.go.id/

BPS. (2019). Status Pekerjaan. Diakses dari: https://sirusa.bps.go.id/

Chatterji, P. \& Frick, K. D. (2005). Does Returning to Work After Childbirth Affect Breastfeeding Practices? Review of Economics of the Household 3: 315-335. Diakses dari www.nber.org/papers/w9630

Depkes. (2010). Menkes Mengajak Seluruh Fasilitas Kesehatan Terapkan 10 Langkah Menuju Keberhasilan Menyusui. Diakses dari http://www.depkes.go.id/

Dinkes Bali. (2018). Laporan Kinerja Instansi Pemerintah Tahun 2017. Diakses dari: http://diskes.baliprov.go.id/

Dinkes Bali. (2016). Profil Kesehatan Provinsi Bali Tahun 2015. Diakses dari: www.depkes.go.id/

Kartikasari, R.I \& Afifah, D.N. (2009). Hubungan Antara Motivasi dengan Pemberian ASI Eksklusif di Desa Balun Kecamatan Turi Kabupaten Lamongan. Jurnal Surya Vol 1 (1). Diakses dari: https://stikesmuhla.ac.id/

Kemenkes RI. (2015). Dukung Ibu Bekerja Beri ASI Eksklusif. Diakses dari: http://www.depkes.go.id/

Notoatmodjo, S. (2009). Pengembangan Sumber Daya Manusia. Jakarta: Rineka Cipta

Nurlely, I.A. (2012). Perbedaan Faktor-Faktor Pemberian ASI Eksklusif di Wilayah Kerja Puskesmas Pancol dan Puskesmas Candilama Kota Semarang. (2012). Jurnal Kesehatan Masyarakat Vol 1 (2). Diakses dari: https://media.neliti.com/

Nuryawati, L.S. (2015). Hubungan antara Pekerjaan dan Motivasi Ibu Menyusui dengan Pelaksanaan Pemberian ASI Eksklusif di Wilayah Kerja UPTD Puskesmas DTP Panongan Kecamatan Jatitujuh Kabupaten Majalengka Tahun 2015. Diakses dari: ejournal.stikesypib.ac.id

Okawary, O. (2015). Hubungan Status Pekerjaan Ibu dengan Pemberian ASI Eksklusif di Wilayah Kerja Puskesmas Seyegan Sleman Yogyakarta. Naskah Publikasi. Yogyakarta: Sekolah Tinggi Ilmu Kesehatan 'Aisyiyah. Diakses dari: digilib.unisayogya.ac.id/
Pratiwi, H.D. (2015). Perbedaan Motivasi Pemberian ASI Eksklusif pada Ibu yang Bekerja dan Tidak Bekerja di Desa Arjasa Kecamtan Arjasa Kabupaten Jember. Skripsi. Tidak dipublikasikan. Diakses dari: https://repository.unej. aca.id

Rahmadhani, E.P., Lubis, G. \& Edison. (2013). Hubungan Pemberian ASI Eksklusif dengan Angka Kejadian Diare Akut pada Bayi Usia 0-1 Tahun di Puskesmas Kuranji Kota Padang. Jurnal Kesehatan Andalas. Diakses dari: http:jurnal.fk.unand.ac.id

Retiyansa, Y. (2018). Hubungan Pengetahuan Tentang ASI Eksklusif dengan Riwayat Pemberian ASI Eksklusif di Desah Makam Haji Sukoharjo. Jurnal Ilmiah Kesehatan Media Husada. Surakarta: Universitas Sebelas Maret. DOI: 10.33475/jikmh.v7i2.26

Ribek, N. \& Kumalasari, N.M.Y. (2014). Motivasi Ibu dalam Pemberian ASI Eksklusif

Soetjiningsih. (2012). ASI: Petunjuk Untuk Tenaga Kesehatan. Jakarta: EGC

Sulistyorini, E. \& Fitriyani. (2011). Gambaran Motivasi Ibu Menyusui dalam Memberikan ASI Eksklusif di Posyandu Melati Desa Malangan Tanduk Ampel Boyolali Tahun 2011. Jurnal Kebidanan Indonesia, Vol 2 (2). Diakses dari: https://jurnal.stikesmus.ac.id/

Walyani, H.S \& Purwoastuti, T.E. (2015). Asuhan Kebidanan Masa Nifas \& Menyusui. Yogyakarta: Pustaka Baru Press 